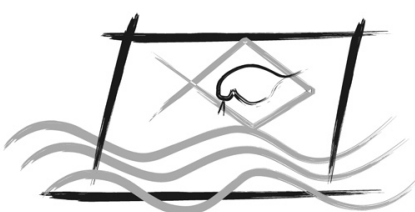

J. Braz. Soc. Ecotoxicol., v. 7, n. 2, 2012, 85-91

doi: $10.5132 / j b s e .2012 .02 .013$

\title{
Effects of sodium and potassium on life history parameters of freshwater cladoceran Pseudosida ramosa
}

\author{
E.C. Freitas ${ }^{1} \&$ O. Rocha ${ }^{2}$ \\ ${ }^{1}$ Post-Graduate Program of Ecology and Natural Resources, Department of Ecology and Evolutionary Biology, Federal University of São \\ Carlos, Rodovia Washington Luis, km 235, CEP 13565-905, São Carlos, São Paulo, Brazil. \\ ${ }^{2}$ Department of Ecology and Evolutionary Biology, Federal University of São Carlos, São Carlos, São Paulo, Brazil.
}

(Received October 02, 2010; Accept June 17, 2011)

\begin{abstract}
In this study, we measured the life history parameters of the tropical cladoceran Pseudosida ramosa at sublethal concentrations of sodium and potassium. The results showed that salinity affected its maximum body length at a concentration of $249 \mathrm{mg} \mathrm{L}^{-1}$ of sodium. There was also an increase in the number of days taken by females to reach maturity at a concentration of $11 \mathrm{mg} \mathrm{L}^{-1}$ of potassium, a reduction in the number of neonates produced by primipara at concentrations ranging from 25 to $249 \mathrm{mg} \mathrm{L}^{-1}$ of sodium, reductions in the survival at concentrations of $249 \mathrm{mg} \mathrm{L}^{-1}$ of sodium and $11 \mathrm{mg} \mathrm{L}^{-1}$ of potassium and reductions in the number of total neonates hatched at concentrations ranging from 41 to $249 \mathrm{mg} \mathrm{L}^{-1}$ of sodium and from 3.6 to $11 \mathrm{mg} \mathrm{L}^{-1}$ of potassium. The concentrations of the both salts that affected the reproduction of $P$. ramosa were lower than those that affected other endpoints.
\end{abstract}

Key words: life history, potassium, Pseudosida ramosa, saline stress, sodium.

Efeitos do sódio e potássio sobre parâmetros da história de vida do cladócero de água doce Pseudosida ramosa

\section{Resumo}

Neste estudo, nós medimos os parâmetros do ciclo de vida de um cladócero tropical Pseudosida ramosa para concentrações subletais de sódio e potássio. Os resultados mostraram que a salinidade afetou seu comprimento corpóreo máximo em uma concentração de $249 \mathrm{mg} \mathrm{L}^{-1}$ de sódio. Houve também um aumento no número de dias para que as fêmeas atingissem a maturidade em uma concentração de $11 \mathrm{mg} \mathrm{L}^{-1}$ de potássio, uma redução no número de neonatas produzidas pela primípara para concentrações que variaram de 25 a $249 \mathrm{mg} \mathrm{L}^{-1}$ de sódio, reduções na sobrevivência para concentrações de $249 \mathrm{mg} \mathrm{L}^{-1}$ de sódio e $11 \mathrm{mg} \mathrm{L}^{-1}$ de potássio e reduções no número de neonatas total eclodidas para concentrações que variaram de 41 a 249 $\mathrm{mg} \mathrm{L}^{-1}$ de sódio e de 3,6 a $11 \mathrm{mg} \mathrm{L}^{-1}$ de potássio. As concentrações dos sais que afetaram a reprodução de $P$. ramosa foram menores do que àquelas que afetaram outros parâmetros.

Palavras-chave: ciclo de vida, potássio, Pseudosida ramosa, sódio, stress salino. 


\section{INTRODUCTION}

The rising salinity in freshwater ecosystems is a problem that is becoming increasingly serious worldwide, but particularly in developing countries, where rapid eutrophication and salinization are occurring (Sarma et al., 2006). Comparative measurements of electrical conductivity in inland freshwater in São Paulo State, Brazil, show that over two decades it increased by more than $200 \%$ in many reservoirs (Tundisi et al., 1988).

Several authors (e.g., Hall \& Burns, 2003; Schallenberg et al., 2003) have reported a reduction in the abundance and diversity of zooplankton communities in temperate regions exposed to salinity increases. However, more information on how the rise in salinity affects ecosystem integrity is needed, in order to predict the impact and rehabilitation of aquatic systems (Nielsen et al., 2003). Therefore, studies on the effect of salinity stress on freshwater organisms are important to predict possible species losses and replacements, among other types of impact. Among suitable test organisms, zooplankton has long been used to assess the impact of environmental change, owing to their key intermediate position in the trophic food web. Salinity changes in freshwater systems can greatly affect the survival and life history (growth and reproduction) of zooplankton populations and, consequently, have an impact on higher trophic levels. Cladocerans, one of the most abundant primary consumer groups in lentic ecosystems, have varying physiological tolerances to several ionic components (Bos et al., 1996) and are good indicators of environmental changes, especially changes in freshwater salinity (Sanchez-Colomer, 1996; Boronat et al., 2001; Amsinck et al., 2003).

To assess the effects of salinity on tropical freshwater plankton species, we measured life history parameters of Pseudosida ramosa (Cladocera, Sididae), a native species in tropical regions (Rey \& Vasquez, 1986; Roa \& Vasquez, 1991; Korovchinsky, 1992; Morrone \& Coscarón, 1998; Sanoamuang, 1998; Elias-Gutierrez et al., 2001; Maiphae et al., 2005; Freitas \& Rocha, 2006), at sublethal concentrations of sodium and potassium. The main aim of this study was to determine salinity thresholds that can have adverse effects on $P$. ramosa in chronic exposures and to compare these thresholds with those known for other species.

\section{MATERIAL AND METHODS}

\section{Organism and culture conditions}

Individuals of the cladoceran species Pseudosida ramosa were originally collected from the Óleo Lake $\left(21^{\circ} 20^{\prime}-21^{\circ} 55^{\prime} \mathrm{S}\right.$ by $47^{\circ} 35^{\prime}-47^{\circ} 55^{\prime} \mathrm{W}$ ), an oxbow lake in the Mogi-Guaçu River flood plain, Jataí Ecological Station, district of Luis Antônio, São Paulo State, Brazil, and were used to establish a culture that has been maintained in our laboratory since 2004 .

Neonatal $P$. ramosa were obtained from continuous cultures in $2 \mathrm{~L}$ glass beakers containing reconstituted soft water at $25 \pm 1{ }^{\circ} \mathrm{C}$, as recommended by the American Society for Testing and Materials (ASTM, 2001). The reconstituted soft water was prepared with $0.03 \mathrm{~g} \mathrm{~L}^{-1} \mathrm{CaSO}_{4} 2 \mathrm{H}_{2} \mathrm{O}, 0.061$ $\mathrm{g} \mathrm{L}^{-1} \mathrm{MgSO}_{4} 7 \mathrm{H}_{2} \mathrm{O}, 0.048 \mathrm{~g} \mathrm{~L}^{-1} \mathrm{NaHCO}_{3}$, and $0.002 \mathrm{~g} \mathrm{~L}^{-1} \mathrm{KCl}$ dissolved in $1 \mathrm{~L}$ of distilled water and had a total hardness equivalent to $40-48 \mathrm{mg} \mathrm{CaCO}_{3} \mathrm{~L}^{-1}$, a $\mathrm{pH}$ range of 7.2-7.6 and a conductivity of $160 \mu \mathrm{S} \mathrm{cm}^{-1}$.

The culture medium was renewed three times weekly. Individuals of $P$. ramosa were maintained under a light: dark photoperiod of 12:12 h, at a density of below 70 individuals per liter and fed daily with the green algae Pseudokirchneriella subcapitata $\left(10^{5}\right.$ cells $\left.\mathrm{mL}^{-1}\right)$ and a suspension of dried baking yeast given as a food supplement $\left(0.05 \mathrm{mg} \mathrm{L}^{-1}\right.$ of dry yeast) as recommended by USEPA (2002). The alga was cultured in CHU-12 medium (Müller, 1972), which was previously autoclaved at $120^{\circ} \mathrm{C}$ and $1 \mathrm{~atm}$ for 20 minutes. The alga was grown at $25 \pm 1{ }^{\circ} \mathrm{C}$, under a light: dark photoperiod of $12: 12 \mathrm{~h}$ and the culture medium was gently aerated. Before using $P$. subcapitata as food, it was centrifuged, washed and resuspended in reconstituted soft water to remove culture nutrients.

\section{Chemicals and test solutions}

$\mathrm{NaCl}$ and $\mathrm{KCl}$ of high purity (>99\%) were purchased from Lafan Química Fina Ltda (Brazil). Stock solutions of $\mathrm{NaCl}$ $\left(10 \mathrm{~g} \mathrm{~L}^{-1}\right)$ and $\mathrm{KCl}\left(100 \mathrm{mg} \mathrm{L}^{-1}\right)$ were prepared by dissolving a weighed amount of each compound in distilled water just before the tests. In turn, the nominal tested concentrations of each compound were obtained by diluting the stock solution in reconstituted soft water. In this study, it was taken into account that the water dilution (reconstituted soft water) used in the tests contained ions of $\mathrm{Na}^{+}$and $\mathrm{K}^{+}$. Their concentrations were added to the final values of the nominal tested concentrations for each ion.

Chemical analysis of test solutions, to confirm the actual concentrations of the toxicants, was not performed, since the salts tested were very unlikely to be lost by evaporation, precipitation, chemical transformation, variations in the oxidation state, or adsorption.

\section{Chronic toxicity tests}

The chronic toxicity tests were carried out in accordance with the guidelines of the Organization for Economic Cooperation and Development (OECD, 2008).

The tests were conducted over the whole life cycle, under the same conditions of temperature and photoperiod as described for the culture procedures. Tests were initiated with neonates $(\leq 24 \mathrm{~h}$ old $)$ obtained from the same bulk culture, born between the $3^{\text {rd }}$ and $5^{\text {th }}$ broods.

In total, ten replicate culture vessels were used for each test solution and for control. The neonates used in the chronic assays were individually cultured in $50 \mathrm{~mL}$ glass beakers containing $20 \mathrm{~mL}$ of the test solution or $20 \mathrm{~mL}$ of the 
reconstituted soft water (control), totaling 10 test organisms per treatment. The assays were performed at the following nominal concentrations: $25,41,72,131$, and $249 \mathrm{mg} \mathrm{L}^{-1}$ for $\mathrm{Na}^{+}$and $1.02,1.26,3.6,6.2$, and $11 \mathrm{mg} \mathrm{L}^{-1}$ for $\mathrm{K}^{+}$. These concentrations were chosen on the basis of the acute toxicity results (Freitas \& Rocha, 2011).

The tests were carried out on a semi-static basis and test solutions were renewed every two days. The individuals were fed daily as previously described. During the experiment, $\mathrm{pH}$, temperature, electrical conductivity, dissolved oxygen, and total hardness were measured every time the test solutions were renewed, to find out whether they were affecting the biological responses or not.

Animals were checked every day at approximately the same hour for mortality and reproductive state. In this study, a dead individual was defined as one showing no heartbeat when examined under the stereomicroscope (Day et al., 1993). Data were assessed by recording the following parameters during the test: primipara lenght $(\mathrm{mm})$, primipara age (days), number of eggs (eggs female ${ }^{-1}$ ) or neonates (neonates female $^{-1}$ ) per primipara, longevity (days), and total number of eggs (eggs female ${ }^{-1}$ ) or neonates (neonates female ${ }^{-1}$ ) per adult female. When neonates were released, they were counted and discarded.

To monitor individual body length, each female was transferred once a day to a watch glass by means of a widepoint Pasteur pipette, care being taken to avoid damaging the organism. The length of the whole body was measured under a stereoscopic microscope, with the aid of a micrometric ruler, from the top of the head to the rear end of the organism (tip of the carapace). Growth curves were fitted to the data by means of the von Bertalanffy equation (von Bertalanffy, 1938), whose parameters were determined by applying the Ford-Walford transformation (Walford, 1946): $\mathrm{L}_{\mathrm{t}}=\mathrm{L} \infty\left[1-\mathrm{e}^{-\mathrm{K}(\mathrm{t}-\mathrm{t})}\right]$, where $\mathrm{L}_{\mathrm{t}}$ is the body length at time $\mathrm{t}$ (in $\mathrm{mm}$ ), $\mathrm{L} \infty$ its maximum value, to which the curve tends asymptotically $(\mathrm{mm}), \mathrm{K}$ the growthrate constant (days ${ }^{-1}$ ), e the base of Napierian logarithms and $\mathrm{t}_{0}$ a time related to the mean length at the moment of birth, $\mathrm{L}_{0}$ (days).

\section{Data treatment and statistical analysis}

The effect of salinity on the life history parameters of $P$. ramosa were expressed as mean values plus standard deviation (SD). Data were first checked for the normality (with the chi-squared test) and homogeneity (with Bartlett's test) of their distribution. To test for significance, a one-way ANOVA was applied to the data. When the ANOVA showed statistical significance, a Tukey test was then applied to the data, to determine which concentrations were significantly different from the control group and of the other treatments. This procedure allowed the determination of the standard NOEC (No Observed Effect Concentration) and LOEC (Lowest Observed Effect Concentration) values. To detect any significant differences in individual growth, the nonparametric Mann-Whitney test (MW) was used. A value of $\alpha \leq 0.05$ was taken to show significance in all tests. All data were analyzed using the computer program TOXSTAT 3.3 (Gulley et al., 1991).

\section{RESULTS}

During the chronic toxicity tests, the measured $\mathrm{pH}$ of the solutions remained within the range 7.2-7.6 and did not vary by more than 1.0 unit in any given test. The temperature ranged from 24.2 to $25.3^{\circ} \mathrm{C}$. The electrical conductivity ranged from 154.6 to $1,351 \mu \mathrm{S} \mathrm{cm}-1$ for $\mathrm{Na}^{+}$and from 145.3 to $272.0 \mu \mathrm{S}$ $\mathrm{cm}^{-1}$ for $\mathrm{K}^{+}$. The oxygen content of the test solutions ranged from 7.6 to $9.3 \mathrm{mg} \mathrm{L}^{-1}$ and water hardness ranged from 44 to $46 \mathrm{mg} \mathrm{CaCO} \mathrm{L}^{-1}$. Thus, all tests met the validity criteria set forth by the OECD guidelines.

The growth results for the $P$. ramosa females are illustrated in Figure 1. In the assay with sodium (a), a modest, but statistically significant decrease in maximum body length was observed between organisms tested with $249 \mathrm{mg} \mathrm{L}^{-1}$ (maximum body length $=2.26 \mathrm{~mm}$ ) and controls $(2.36 \mathrm{~mm}$ ) $(\mathrm{MW}=960.5 ; \mathrm{p}=0.03)$. No difference was found between controls and organisms treated with lower concentrations of $\mathrm{Na}^{+}$(between control and $25 \mathrm{mg} \mathrm{L}^{-1}, \mathrm{MW}=1,431$ and $\mathrm{p}=$ 0.76 ; for $41 \mathrm{mg} \mathrm{L}^{-1}, \mathrm{MW}=1,283$ and $\mathrm{p}=0.85$; for $72 \mathrm{mg} \mathrm{L}^{-1}$, $\mathrm{MW}=1,017$ and $\mathrm{p}=0.20$; for $131 \mathrm{mg} \mathrm{L}^{-1}, \mathrm{MW}=997$ and $\mathrm{p}=$ $0.08)$. No significant difference in maximum body length was found in the chronic toxicity test with potassium (b) (between control and $1.02 \mathrm{mg} \mathrm{L}^{-1}, \mathrm{MW}=1,466$ and $\mathrm{p}=0.18$; for 1.26 $\mathrm{mg} \mathrm{L}^{-1}, \mathrm{MW}=1,615$ and $\mathrm{p}=0.30$; for $3.6 \mathrm{mg} \mathrm{L}^{-1}, \mathrm{MW}=1,999$ and $\mathrm{p}=0.95$; for $6.2 \mathrm{mg} \mathrm{L}^{-1}, \mathrm{MW}=2,014$ and $\mathrm{p}=0.46$; for 11 $\mathrm{mg} \mathrm{L}^{-1}, \mathrm{MW}=1,625$ and $\mathrm{p}=0.62$ ).

Figures 2 and 3 showed life history parameters of $P$. ramosa under influence of sodium and potassium, respectively.

The mean body length at the first reproduction (primipara) did not differ significantly from the control for either sodium or potassium treatment at any concentration. However, for females cultured in $11 \mathrm{mg} \mathrm{L}^{-1} \mathrm{~K}^{+}$, there was an increase in the number of days taken to reach maturity (11.2 \pm 2.3 days), relative to control $(8.75 \pm 1.16$ days $)\left(\mathrm{F}_{5,47}=4.29 ; \mathrm{p}=0.003\right)$.

Regarding the number of eggs and neonates produced by the primipara, we found significant differences from the control $\left(2.40 \pm 1.43\right.$ neonates female $\left.{ }^{-1}\right)$ in females cultured at the concentrations of $25\left(0.80 \pm 0.92\right.$ neonates female $\left.{ }^{-1}\right)$, $41\left(0.60 \pm 0.97\right.$ neonates female $\left.{ }^{-1}\right), 72(0.60 \pm 0.70$ neonates female $\left.{ }^{-1}\right), 131\left(0.58 \pm 0.92\right.$ neonates female $\left.{ }^{-1}\right)$, and $249 \mathrm{mg} \mathrm{L}^{-1}$ $\mathrm{Na}^{+}\left(0.58 \pm 0.93\right.$ neonates female $\left.{ }^{-1}\right)$, in all of which production of neonates was reduced $\left(\mathrm{F}_{5,54}=4.00 ; \mathrm{p}=0.004\right)$.

Longevities of $P$. ramosa were significantly lower than control longevities $\left(43.6 \pm 14.5\right.$ days for $\mathrm{Na}^{+}$and $51.0 \pm 12.1$ days for $\left.\mathrm{K}^{+}\right)$at the concentrations of $249 \mathrm{mg} \mathrm{L}^{-1} \mathrm{Na}^{+}(23.6 \pm$ 15.2 days $)\left(\mathrm{F}_{5,54}=2.61 ; \mathrm{p}=0.03\right)$ and $11 \mathrm{mg} \mathrm{L}^{-1} \mathrm{~K}^{+}(28.5 \pm$ 15.6 days) $\left(\mathrm{F}_{5,54}=2.48 ; \mathrm{p}=0.04\right)$.

The total number of eggs produced during the whole life cycle of $P$. ramos $a$ under the sodium and potassium treatments did not differ significantly from control. In contrast, for the 

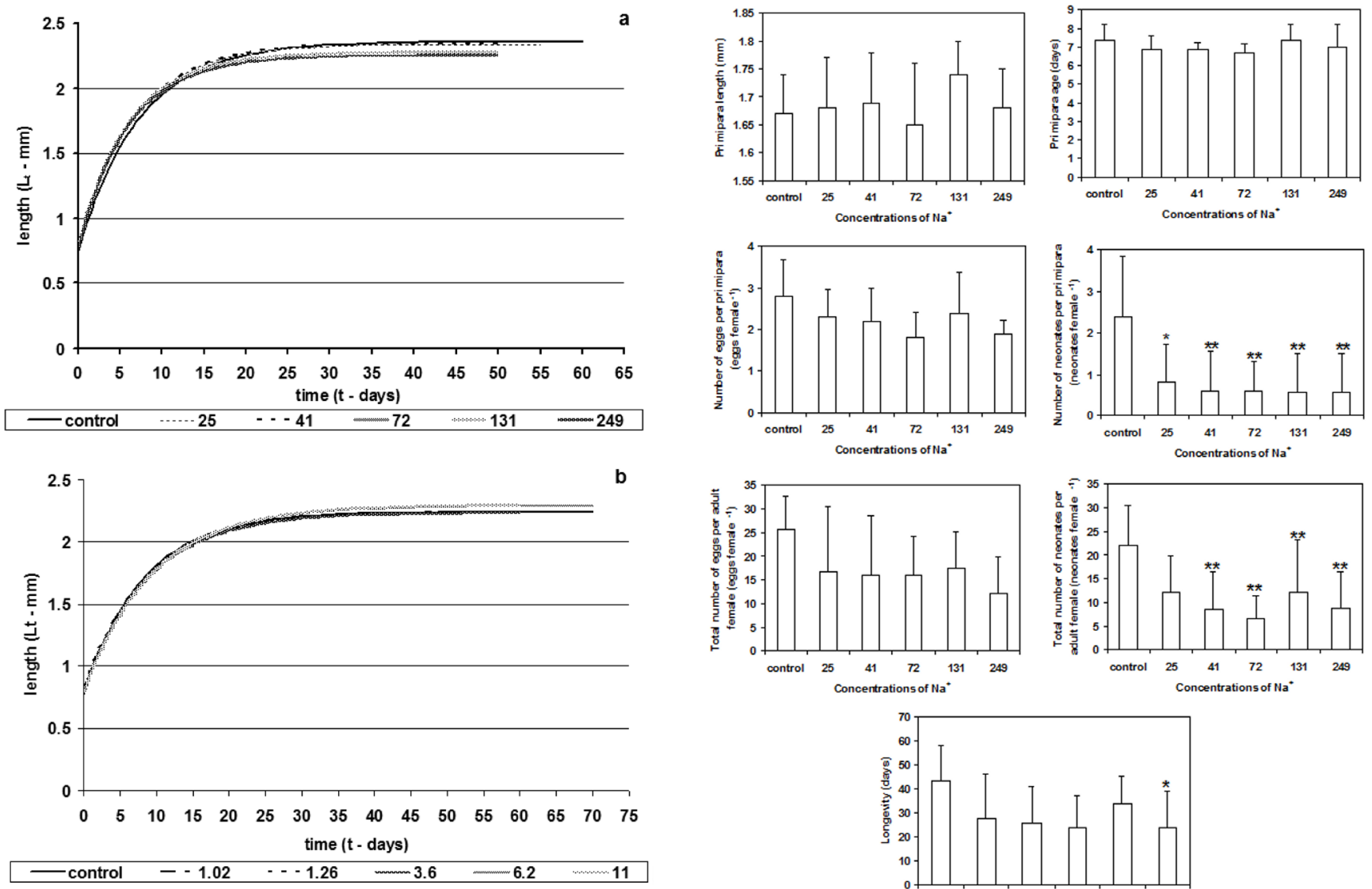

Figure 1 - Growth curves of body length of $P$. ramosa during chronic toxicity tests with (a) sodium $\left(\mathrm{mg} \mathrm{L}^{-1}\right)$ and (b) potassium $\left(\mathrm{mg} \mathrm{L}^{-1}\right)$.

total number of neonates, there was a reduction in the number of individuals hatched at the concentrations of $41(8.60 \pm 7.90$ neonates female $\left.{ }^{-1}\right), 72\left(6.60 \pm 4.90\right.$ neonates female $\left.{ }^{-1}\right), 131$ $\left(12.0 \pm 11.3\right.$ neonates female $\left.{ }^{-1}\right)$ and $249 \mathrm{mg} \mathrm{L}^{-1} \mathrm{Na}^{+}(8.89 \pm$ 7.44 neonates female $\left.{ }^{-1}\right)\left(\mathrm{F}_{5,53}=5.09 ; \mathrm{p}=0.001\right)$, and $3.6(10.0$ \pm 4.92 neonates female $\left.{ }^{-1}\right), 6.2\left(9.89 \pm 4.65\right.$ neonates female $\left.^{-1}\right)$ and $11 \mathrm{mg} \mathrm{L}^{-1} \mathrm{~K}^{+}\left(9.88 \pm 5.28\right.$ neonates female $\left.{ }^{-1}\right)\left(\mathrm{F}_{5,47}=4.17\right.$; $\mathrm{p}$ $=0.003)$, relative to the control $\left(22.2 \pm 8.23\right.$ neonates female ${ }^{-1}$ for $\mathrm{Na}^{+}$and $18.8 \pm 8.22$ neonates female ${ }^{-1}$ for $\mathrm{K}^{+}$).

The values calculated for NOEC and LOEC in the chronic toxicity tests with $\mathrm{Na}^{+}$and $\mathrm{K}^{+}$are presented in Table 1 .

\section{DISCUSSION}

The cladoceran crustaceans are aquatic invertebrates widely used to assess environmental quality (ISO, 1996; USEPA, 2002). However, certain regions, most cladocerans used to monitor the environment are exotic species. This often generates results that do not reflect the real situation in the local area. In this study, the idea was to use Pseudosida ramosa, a species native to the tropics, to assess the possible effects of salinization on freshwater cladocerans.

With respect to the growth curves, a modest but statistically significant decrease in maximum body length was observed between the control group and the group exposed to the highest

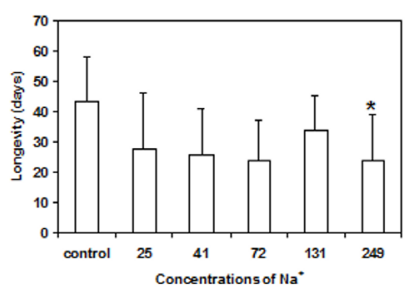

Figure 2 - Life history parameters of $P$. ramosa under influence of various concentrations of sodium $\left(\mathrm{mg} \mathrm{L}^{-1}\right)$. Values are mean of 10 replicates $( \pm \mathrm{SD})$. Statistically significant differences in relation to the control (Tukey's test) are indicated by $*(\mathrm{p} \leq 0.05)$ or $* *(\mathrm{p} \leq 0.01)$.

concentration (249 $\mathrm{mg} \mathrm{L}^{-1}$ ) of sodium. Even though there was no significant difference between any other treatment group (for $\mathrm{Na}^{+}$or $\mathrm{K}^{+}$) and the control animals, there was a tendency for the maximum body length $(\mathrm{L} \infty)$ to be shorter in the organisms subjected to chronic toxicity tests with sodium. Such a tendency might be due to physiological stress caused by raised salinity, in that the animal would have to allocate energy to osmoregulation that would normally be employed in growth of the body. It may be of interest that cladocerans found successfully colonizing brackish habitats were smaller than those in freshwater populations and showed a reduced breeding rate (Arne'r \& Koivisto, 1993). No size-reduction tendency was observed in the group of $P$. ramosa subjected to chronic toxicity tests with up to $11 \mathrm{mg} \mathrm{L}^{-1}$ of $\mathrm{K}^{+}$. However, Utz $\&$ Bohrer (2001) found significant reductions in the growth of D. similis when exposed to potassium chloride concentrations higher than $80 \mathrm{mg} \mathrm{L}^{-1}$.

Life history traits of P. ramosa were affected by the increase of salinity in our study. The most dramatic change caused by sodium was in the number of neonates. Concentrations higher than $25 \mathrm{mg} \mathrm{L}^{-1}$ were sufficient to prevent the normal development of eggs in the incubation chamber of the females. Several authors (e.g., Baird et al., 1991; Guilhermino et al., 

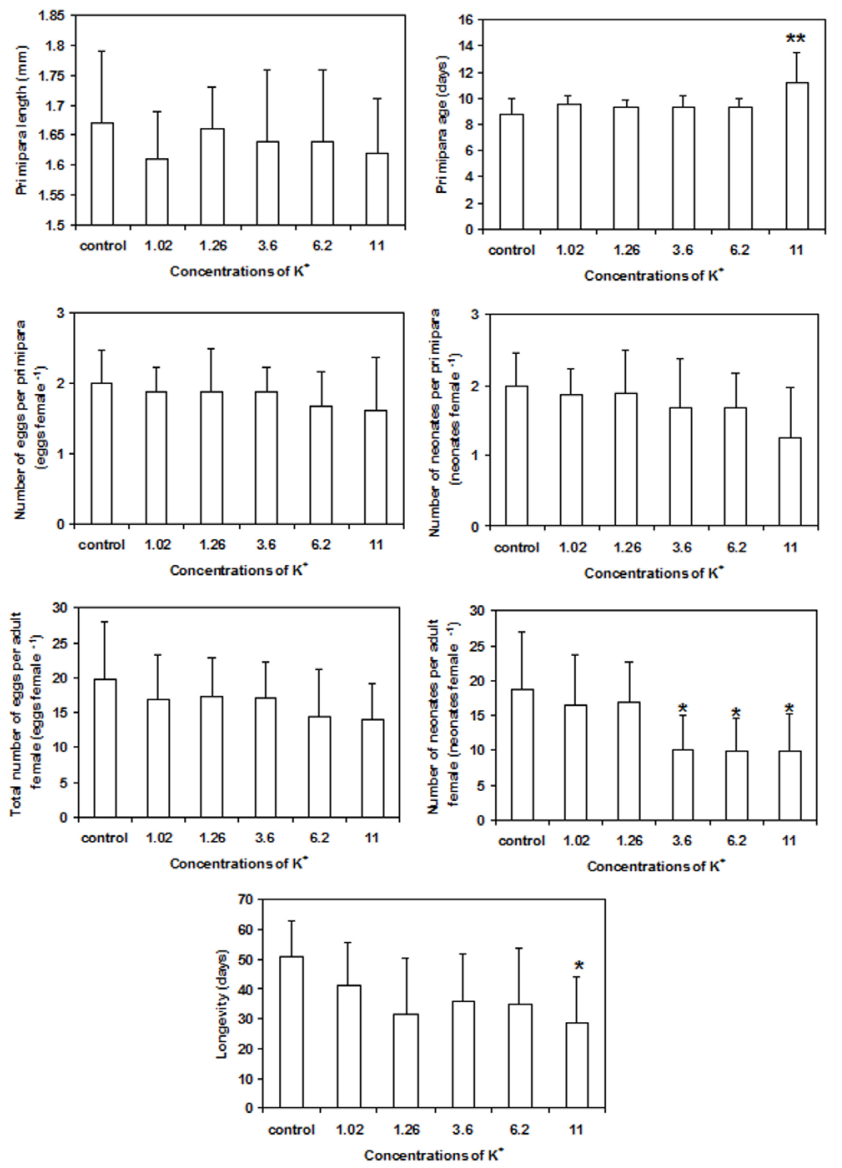

Figure 3 - Life history parameters of $P$. ramosa under influence of various concentrations of potassium $\left(\mathrm{mg} \mathrm{L}^{-1}\right)$. Values are mean of 10 replicates $( \pm$ $\mathrm{SD}$ ). Statistically significant differences in relation to the control (Tukey's test $)$ are indicated by $*(\mathrm{p} \leq 0.05)$ or $* *(\mathrm{p} \leq 0.01)$.

Table 1 - NOEC and LOEC values for each life history parameter of $P$. ramosa exposed to various concentrations of sodium and potassium throughout the life cycle $(\mathrm{n}=10)$

\begin{tabular}{lcccccc}
\hline \multirow{2}{*}{ Life history parameters } & \multicolumn{2}{c}{$\mathrm{Na}^{+}\left(\mathrm{mg} \mathrm{L}^{-1}\right)$} & & \multicolumn{2}{c}{$\mathrm{K}^{+}\left(\mathrm{mg} \mathrm{L}^{-1}\right)$} \\
\cline { 2 - 3 } \cline { 5 - 7 } & NOEC & LOEC & & NOEC & LOEC \\
\hline Body length (mm) & 131 & 249 & & - & - \\
Primipara age (days) & - & - & & 6.2 & 11 \\
Number of neonates per primipara & $<25$ & 25 & & - & - \\
Longevity (days) & 131 & 249 & & 6.2 & 11 \\
Total number of neonates per female & 25 & 41 & & 1.26 & 3.6 \\
\hline
\end{tabular}

(-) means that the value cannot be calculated.

1999) found that sodium (present as sodium bromide) caused abnormal embryonic development, an increased level of abortion and a reduced total number of neonates in Daphnia magna.

Potassium also negatively affected the number of neonates hatched, at concentrations above $3.6 \mathrm{mg} \mathrm{L}^{-1}$, and therefore was about 11.4 times more toxic than sodium for the production of neonates by $P$. ramosa. Additionally, maturation (primipara age) was delayed significantly at the highest concentration (11 $\left.\mathrm{mg} \mathrm{L}^{-1}\right)$ of $\mathrm{K}^{+}$. Similarly, Teschner (1995) concluded that clones of D. magna grown under brackish conditions matured later than under freshwater conditions.

Both salts $\left(\mathrm{Na}^{+}\right.$and $\left.\mathrm{K}^{+}\right)$reduced the longevity of $P$. ramosa at the highest concentrations tested $\left(249\right.$ and $11 \mathrm{mg} \mathrm{L}^{-1}$, respectively). Nielsen etal.(2003) stated that microinvertebrates, freshwater algae and aquatic plants appear to be the biological communities least tolerant to increases in salinity.

A small increase in salinity seems to be clearly deleterious for the indigenous species $P$. ramosa. This becomes clear when we compared the values of NOEC and LOEC for this species with other freshwater cladocerans. For the daphnid Ceriodaphnia dubia exposed to sodium, Aragão \& Pereira (2003) found a NOEC for reproduction that varied from 25 to $50 \mathrm{mg} \mathrm{L}^{-1}$, in agreement with the value of $44 \mathrm{mg} \mathrm{L}^{-1}$ reported by Harmon et al. (2003). In the latter study, the LOEC for reproduction was $85 \mathrm{mg} \mathrm{L}^{-1}$ for this species, and the NOEC and LOEC for reproduction of Daphnia ambigua were found to be identical to those of $C$. dubia. Hence, in chronic toxicity tests with $\mathrm{Na}^{+}, P$. ramosa was as sensitive as, or more sensitive than, either $C$. dubia or D. ambigua, having a NOEC and LOEC for reproduction of 25 and $41 \mathrm{mg} \mathrm{L}^{-1}$, respectively. When $P$. ramosa was exposed to potassium, the NOEC and LOEC for reproduction were found to be 1.26 and $3.6 \mathrm{mg} \mathrm{L}^{-1}$, respectively. Utz \& Bohrer (2001) tested the chronic toxicity of potassium to Daphnia similis and observed a LOEC for reproduction of $60 \mathrm{mg} \mathrm{L}^{-1}$.

Note also that the concentrations of both salts that affected reproduction in $P$. ramosa were lower than those that affected the body length (for $\mathrm{Na}^{+}$), age at first reproduction (for $\mathrm{K}^{+}$) and longevity (for both salts) (Table 1).

Salinity is an important and crucial factor in determining the presence, dominance and succession of organisms. This study gives an insight into how an increase in the level of salts affects significantly survival and life history traits, which can cause changes in the zooplankton community structure. Other authors (e.g., Nielsen et al., 2003; Bailey et al., 2004) state that, if salinity rises very rapidly, organisms cannot adapt and freshwater taxa can become locally extinct, transferring dominance to salt-tolerant taxa.

The present results suggest that more attention should be paid to potassium as a toxicant to freshwater biota, seeing that it was about 11.4 times more toxic than sodium for the production of neonates by $P$. ramosa. The present study also suggest that the increasing salinity observed in many freshwater systems may have dramatic implications for species composition and biodiversity, affecting the reproduction of $P$. ramosa and eliminating this species if salinity concentrations remain above its tolerance levels. Further experiments with freshwater species under brackish and saline conditions are required in order to understand how freshwater species adapt their physiology to such stressful environments. Studies in mesocosms (more realistic and complex scenarios) may be useful for a deeper understanding of the effects of salinity and of its interactions with other factors (e.g., temperature, 
nutrients), at the guild/community level, thus generating more ecologically relevant information.

\section{ACKNOWLEDGMENTS}

We are grateful to São Paulo State Research Aid Foundation (FAPESP) for financial support (process 06/59397-3).

\section{REFERENCES}

AMSINCK, S.L., JEPPESEN, E. \& RYVES, D., 2003, Cladoceran stratigraphy in two brackish lakes with special reference to changes in salinity, macrophyte abundance and fish predation. $J$. Paleolimnol., 29: 495-507. doi: 10.1023/A:1024470329314.

ARAGÃO, M.A. \& PEREIRA, E.V., 2003, Sensitivity of Ceriodaphnia dubia of different ages to sodium chloride. Bull. Environ. Contam. Toxicol., 70: 1247-1250. doi: 10.1007/s00128003-0116-z.

ARNE'R, M. \& KOIVISTO, S., 1993, Effects of salinity on metabolism and life history characteristics of Daphnia magna. Hydrobiologia, 259: 69-77. doi: 10.1007/BF00008373.

ASTM - American Society for Testing Materials, 2001, Standard guide for conducting acute toxicity testing on test materials with fishes, macroinvertebrates, and amphibians. E729-E796. ASTM, West Conshohocken, PA.

BAILEY,S.A.,DUGGAN,I.C., OVERDIJK, C.D.A.V.,JOHENGEN, T.H., REID, D.F. \& MACISAAC, H.J., 2004, Salinity tolerance of diapausing eggs of freshwater zooplankton. Freshwater Biol., 49: 286-295. doi: 10.1111/j.1365-2427.2004.01185.x.

BAIRD, D.J., BARBER, I., SOARES, A.M.V.M. \& CALOW, P., 1991, An early life-stage test with Daphnia magna Straus: An alternative to the 21-day chronic test? Ecotox. Environ. Safe., 22: 1-7. doi: 10.1016/0147-6513(91)90040-V.

BORONAT, L., MIRACLE, M.R. \& ARMENGOL, X., 2001, Cladoceran assemblages in a mineralization gradient. Hydrobiologia, 442: 75-88. doi: 10.1023/A:1017522004975.

BOS, D.G., CUMMING, B.F., WATTERS, C.E. \& SMOL, J.P., 1996, The relationship between zooplankton, conductivity and lake-water ionic composition in 111 lakes from the Interior Plateau of British Columbia, Canada. Int. J. Salt Lake Res., 5: 1-15. doi: 10.1007/BF01996032.

DAY, K.E., HOLTZE, K.E., METCALFE-SMITH, J.L., BISHOP, C.T. \& DUTKA, B.J., 1993, Toxicity of leachate from automobile tires to aquatic biota. Chemosphere, 27: 665-675. doi: 10.1016/0045-6535(93)90100-J.

ELÍAS-GUTIÉRREZ, M., SMIRNOV, N.N., SUÁREZMORALES, E. \& DIMAS-FLORES, N., 2001, New and little known cladocerans (Crustacea: Anomopoda) from southeastern Mexico. Hydrobiologia, 442(1-3): 41-54. doi: 10.1023/A:1017506804840.

FREITAS, E.C. \& ROCHA, O., 2006, The cycle life of Pseudosida ramosa, Daday 1904, an endemic neotropical cladoceran. Acta Limnol. Bras., 18: 293-303.

FREITAS, E.C. \& ROCHA, O., 2011, Acute toxicity tests with the tropical cladoceran Pseudosida ramosa: The importance of using native species as test organisms. Arch. Environ. Contam. Toxicol., 60: 241-249. doi: 10.1007/s00244-010-9541-2.

GUILHERMINO, L., SOBRAL, O., CHASTINET, C., RIBEIRO, R., GONÇALVES, F., SILVA, M.C. \& SOARES, A.M.V.M., 1999, A Daphnia magna first-brood chronic test: an alternative to the conventional 21-day chronic bioassay? Ecotox. Environ. Safe., 42: 67-74. doi: 10.1006/eesa.1998.1730.
GUlleY, D.D., BOETTER, A.M. \& BERGMAN, H.L., 1991, TOXSTAT 3.3, Computer Program.

HALL, C.J. \& BURNS, C.W., 2003, Responses of crustacean zooplankton to seasonal and tidal salinity changes in the coastal Lake Waihola, New Zealand. New Zeal. J. Mar. Fresh., 37: 31 43.

HARMON, S.M., SPECHT, W.L. \& CHANDLER, G.T., 2003, A comparison of the daphnids Ceriodaphnia dubia and Daphnia ambigua for their utilization in routine toxicity testing in the southeastern United States. Arch. Environ. Contam. Toxicol., 45: 79-85. doi: 10.1007/s00244-002-0116-8.

ISO - International Organization for Standardization, 1996, Water quality-determination of the inhibition of the mobility of Daphnia magna Straus (Cladocera: Crustacea). ISO6341-1996. ISO, Geneva, Switzerland.

KOROVCHINSKY, N.M., 1992, Sididae \& Holopedidae. In: N. M. Korovchinsky (ed.), Guides to the identificantion of microinvertebrates of the continental waters of the world (zooplankton guides) 3. SPB Academic Publishing, Netherlands.

MAIPHAE, S., PHOLPUNTHIN, P. \& DUMONT, H.J., 2005, Species richness of the Cladocera (Branchiopoda: Anomopoda and Ctenopoda) in southern Thailand, and its complementarity with neighboring regions. Hydrobiologia, 537: 147-156. doi: 10.1007/s10750-004-2791-0.

MORRONE, J.J. \& COSCARÓN, S., 1998, Biodiversidad de artrópodos argentinos: una perspectiva biotaxonómica. Ediciones SUR, La Plata, 599p.

MÜLLER, H., 1972, Wachstum and phosphatbedarf von Nitzschia actinastroides (Lemn.) v. Goor in statischer und homokontiuierliecher Kultur unter Phosphatlimitierung. Arch. Hydrobiol. Suppl., 38: 399-484.

NIELSEN, D.L., BROCK, M.A., REES, G.N. \& BALDWIN, D.S., 2003, Effects of increasing salinity on freshwater ecosystems in Australia. Aust. J. Bot., 51: 655-665. doi: 10.1071/BT02115.

OECD - Organization for Economic Cooperation and Development, 2008, Guidelines for Testing of Chemicals. Daphnia magna Reproduction Test. OECD 211. Paris, France.

REY, J. \& VASQUEZ, E., 1986, Cladocères de quelques corps d'eaux du bassin moyen de l'Orénoque (Vénézuéla). Ann. Limnol. - Int. J. Lim., 22(2): 137-168. doi: 10.1051/limn/1986013.

ROA, E.Z. \& VASQUEZ, W., 1991, Additional cladoceran records for Mantecal and new for Venezuela. Hydrobiologia, 225: 45-62. doi: 10.1007/BF00028384

SANCHEZ-COLOMER, M.G., 1996, El uso del zooplankton como indicador biologico de la calidad del agua en 26 embalses espanoles. Ingeniería Civil, 105: 55-64.

SANOAMUANG, L., 1998, Contributions to the knowledge of the Cladocera of north-east Thailand. Hydrobiologia, 362(1-3): 4553. doi: 10.1023/A:1003111401684

SARMA, S.S.S., NANDINI S., MORALES-VENTURA, J., DELGADO-MARTÝNEZ，I. \& GONZÁLEZ-VALVERDE, L., 2006, Effects of $\mathrm{NaCl}$ salinity on the population dynamics of freshwater zooplankton (rotifers and cladocerans). Aquat. Ecol., 40: 349-360. doi: 10.1007/s10452-006-9039-1.

SCHALLENBERG, M., HALL, C.J. \& BURNS, C.W., 2003, Consequences of climate-induced salinity increases on zooplankton abundance and diversity in coastal lakes. Mar. Ecol. - Prog. Ser., 251: 181-189. doi: 10.3354/meps251181.

TESCHNER, M., 1995, Effects of salinity on the life history and fitness of Daphnia magna: variability within and between populations. Hydrobiologia, 307: 33-41. doi: 10.1007/BF00031995.

TUNDISI, J.G., MATSUMURA-TUNDISI, T., HENRY, R. ROCHA, O.\& HINO, K., 1988, Comparação do estado trófico de 
23 reservatórios do Estado de São Paulo: Eutrofização e manejo, pp. 165-204. In: J.G. Tundisi (org.), Limnologia e manejo de represas, 1o vol, 432 p., EDUSP, São Paulo.

USEPA - United States Environmental Protection Agency, 2002, Methods for measuring the acute toxicity of effluents and receiving waters to freshwater and marine organisms. USEPA, Washington, DC.

UTZ, L.R.P. \& BÖHRER, M.B.C., 2001, Acute and chronic toxicity of potassium chloride $(\mathrm{KCl})$ and potassium acetate $\left(\mathrm{KC}_{2} \mathrm{H}_{3} \mathrm{O}_{2}\right)$ to Daphnia similis and Ceriodaphnia dubia (Crustacea, Cladocera). Bull. Environ. Contam. Toxicol., 66: 379-385. doi: 10.1007/ s001280016.

VON BERTALANFFY, L.A., 1938, A quantitative theory of organic growth. Hum. Biol., 10: 181-213.

WALFORD, L.A., 1946, A new graphic method of describing the growth of animals. Biol. Bull., 90: 141-147. 